\title{
The Potential of the Reed as a Regenerative Building Material-Characterisation of Its Durability, Physical, and Thermal Performances
}

\author{
Raphaele Malheiro ${ }^{1}$ (D), Adriana Ansolin ${ }^{1}$, Christiane Guarnier ${ }^{2}$, Jorge Fernandes ${ }^{1}$ (D), Maria Teresa Amorim ${ }^{3} \mathbb{D}$, \\ Sandra Monteiro Silva ${ }^{1}$ (D) and Ricardo Mateus ${ }^{1, *(D)}$ \\ 1 Institute for Sustainability and Innovation in Structural Engineering (ISISE), University of Minho, \\ 4800-058 Guimarães, Portugal; raphamalheiro@gmail.com (R.M.); pg37064@alunos.uminho.pt (A.A.); \\ jepfernandes@me.com (J.F.); sms@civil.uminho.pt (S.M.S.) \\ 2 Federal Center for Technological Education "Celso Suckow da Fonseca" (CEFET/RJ), Rio de Janeiro, \\ RJ 20271-110, Brazil; christiane.guarnier@cefet-rj.br \\ 3 Centre for Textile Science and Technology (2C2T), University of Minho, 4800-058 Guimarães, Portugal; \\ mtamorim@det.uminho.pt \\ * Correspondence: ricardomateus@civil.uminho.pt
}

check for

updates

Citation: Malheiro, R.; Ansolin, A.; Guarnier, C.; Fernandes, J.; Amorim, M.T.; Silva, S.M.; Mateus, R. The

Potential of the Reed as a

Regenerative Building MaterialCharacterisation of Its Durability, Physical, and Thermal Performances. Energies 2021, 14, 4276. https:// doi.org/10.3390/en14144276

Academic Editor: Paulo Santos

Received: 9 June 2021

Accepted: 12 July 2021

Published: 15 July 2021

Publisher's Note: MDPI stays neutral with regard to jurisdictional claims in published maps and institutional affiliations.

Copyright: (C) 2021 by the authors. Licensee MDPI, Basel, Switzerland. This article is an open access article distributed under the terms and conditions of the Creative Commons Attribution (CC BY) license (https:// creativecommons.org/licenses/by/ $4.0 /)$.
Abstract: Knowing the properties of vernacular materials is crucial to heritage conservation and to develop innovative solutions. Reed, considered to be a carbon-neutral and a carbon dioxide sink material, has been used for centuries for diverse uses. Its high availability and properties made it a popular building material, including in Portuguese vernacular architecture. An experimental investigation was conducted to evaluate the physical performance, thermal performance, and durability of the reed found in Portugal since the characterisation of this material was not found in previous studies. The influence of geometric characteristics and the presence of nodes on these properties were also analysed, and the results showed that they are irrelevant. The studied reeds were found to have an adequate thermal performance to be used as thermal insulation. Their thermal resistance $\left(1.8 \mathrm{~m}^{2} \cdot{ }^{\circ} \mathrm{C} / \mathrm{W}\right)$ and thermal conductivity $\left(0.06 \mathrm{~W} / \mathrm{m} \cdot{ }^{\circ} \mathrm{C}\right)$ are under the requirements defined by Portuguese regulations on thermal insulation materials. Overall, the physical characteristics (moisture content, density, and retraction) are compatible to its use in the construction. Concerning durability, there was only a trend for mould growth in particular environments. The results provide valuable data to be considered in the development of new construction products based on this natural and renewable material. Additionally, considering the studied samples, the reed found in Portugal has characteristics suitable for use as a building material, especially as a thermal insulation material.

Keywords: reed (Arundo donax); material characterisation; sustainability; natural materials; vernacular architecture

\section{Introduction}

Reed has been used for thousands of years in diverse uses by many cultures [1-3]. The reed has been a conventional construction material since ancient times. It was used to make baskets, fences, windbreakers, building walls, roofs, floors, shading barriers, and temporary shelters for men and animals; music instruments; paper; and bio-fuel. Its characteristics, such as its high availability, lightweight stem, and fair mechanical strength and high flexibility (due to the tubular shape of the stem), has allowed for different uses of reed and made it a popular component as a construction material [2-5].

Its low mechanical strength and easy combustion have made it difficult to use in building structures, being more commonly used in ceilings or supports for covering roofs, wall panelling to improve their thermal performance, or to complement the earthquake resistance of internal and external walls [3]. However, the solution adopted in the construc- 
tion of the external walls of earthquake-resistant buildings with mats of Arundo donax L. in Calabria, Italy, has shown good durability since many examples are still perfectly intact [3].

Around the world, it is possible to see vernacular buildings entirely built out of reeds, just with some construction elements (walls and ceilings), and using reeds together with other materials [6]. In Portuguese vernacular architecture, the reed was also used as a construction material, particularly in the southern region, probably due to its high availability. However, since it is spread throughout the Portuguese territory [7], its use in vernacular architecture can also be found in other regions of mainland and island Portugal [8,9].

Reed was used mainly as an element for thermal insulation in walls [10] and roofs. The encaniçado is an example of the use of reeds in the construction of roofs (Figure 1). This technique allows for a roof to achieve better thermal performance [11], and it is widely used in the vernacular buildings of the Alentejo and Algarve regions in noble and common buildings. The encaniçado consists of rows of reeds tied together [12] and to the structural timber beams. In some cases, a layer of mortar is applied over the reeds to flatten the surface and connect them to the roof tiles that are placed over the mortar.

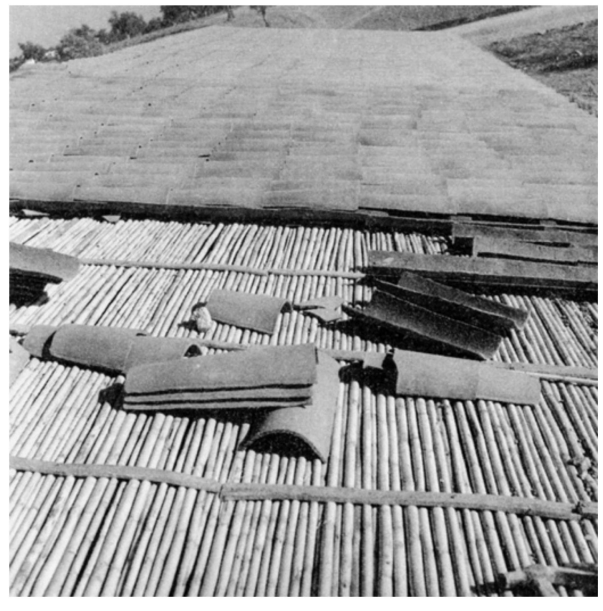

(a)

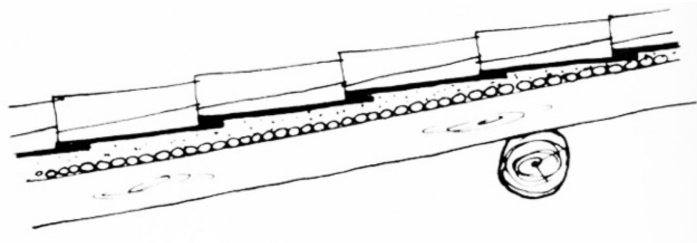

(b)

Figure 1. Use of reed for roof construction: (a) common gable building [8] and (b) section of a roof [8].

Concerning the use of reed as an element for thermal insulation in walls, the walls of palheiros, and the tabique technique are important examples of Portuguese vernacular architecture using reeds. Palheiros are palafitic timber buildings, and although their timber walls usually just have an air cavity, there are records of palheiros in Leirosa (near Figueira da Foz) in which the cavity of the external wall was filled with reeds to improve thermal insulation [8,13] (Figure 2). Reed is also found in earth-filled timber frame walls such as the tabique. The tabique technique can be found almost everywhere in Portugal [14]. It is part of the Portuguese heritage, and similar techniques are applied worldwide [15]. In brief, a tabique is formed by a regular timber frame covered with an earth mortar [14,15]. In Algarve, more specifically in the cities of Lagos and São Brás de Alportel, there are examples where the wooden structure of the tabique walls was replaced by reed panels [16]. 


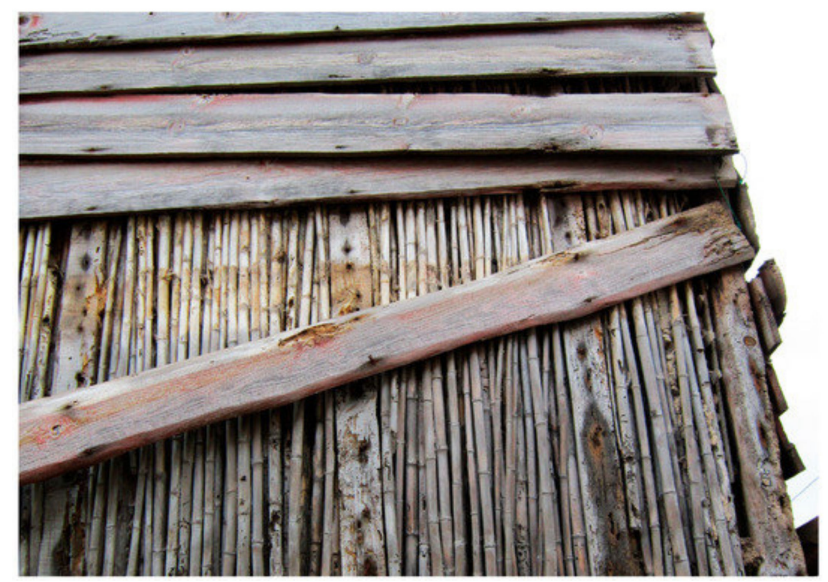

Figure 2. Use of reed for wall construction: palheiro in Leirosa [13].

Similar solutions are used worldwide. For example, in Italy, there is a building system uses a timber-framed supporting structure and a sheathing composed of two mats made of Arundo donax L. fixed to the walls and then covered with a layer of lime and cement plaster [3].

Knowing the properties of the natural materials used in vernacular architecture is crucial to ensure successful heritage conservation, optimise the use of these materials, and develop innovative solutions. In general, the characterisation of natural materials is a challenge for researchers. The high variability in their properties and the absence of specific standards are the main barriers to these materials characterisation [17]. In the particular case of reeds, from the literature review, it was verified that only a few studies have presented their characteristics.

Regarding physical characteristics, the research results are even scarcer. Phragmites australis (PA) (common reed) and Arundo donax (AD) (giant reed) are frequently mentioned in these studies on natural building materials. However, it is important to note that these species have a marked difference in their geometry, particularly in average diameter: around 1.0-2.5 cm for PA [18,19] and 2.5-5.0 cm for AD [19,20]. In this sense, the comparison of results from different studies should be made with caution.

Concerning thermo-acoustic properties, different approaches to characterisation have been identified. Some studies have evaluated the thermo-acoustic potential of panels where the reed is the main material, and others have evaluated panels made only with reed [6,21-23]. Both approaches highlight the thermal insulation potential of the reed. Regarding the panels made only with the reed, the review research carried out by Asdrubali et al. [24] showed thermal conductivity values for the reed of between 0.045 and $0.056 \mathrm{~W} / \mathrm{m} \cdot{ }^{\circ} \mathrm{C}$. Asdrubali et al. [22] presented a thermo-acoustic characterisation of reed panels (PA) while considering different geometries, densities, humidity rates, and stems shapes in experimental research. The maximum diameter of the used reed was $1.5 \mathrm{~cm}$. The thermal characterisation was carried out in a guarded hot plate and hotbox apparatus. According to the authors [22], the layout and characteristics of the reeds did not strongly influence the equivalent thermal conductivity, reaching values between 0.055 and $0.065 \mathrm{~W} / \mathrm{m} \cdot{ }^{\circ} \mathrm{C}$. However, the acoustic behaviour was strongly affected by the stem configuration. Since there was a significant difference in the average diameter of the different reed species, it is essential to understand whether these conclusions apply, for example, to panels made with AD.

Regarding a panel where the reed is the main material, the AD harvested in Portugal was used in a prototype of a building solution based on earth and reeds (stem and fibres) [25]. The prototype built in Lisbon had its indoor and outdoor temperatures monitored during the different seasons. The researchers [25] concluded that the solution contributed to controlling the interior air temperature, given the thermal amplitudes that were registered outside. 
Molari et al. [26] used the same bamboo standards to evaluate the mechanical properties of reed (AD). According to the results, the reed's compressive strength (127.4 MPa) was $20 \%$ higher than the tensile strength $(103.7 \mathrm{MPa})$ and almost twice the axial compressive strength (57.0 MPa). On the other hand, the axial Young's modulus under tension $(15.3 \mathrm{MPa})$ was similar to that under compression (13.4 MPa) and about three times higher than the shear modulus (2.96 MPa). According to the authors [26], the results showed good mechanical properties of the reed that were similar to those of various species of bamboo used in constructions. However, it is important to note that, given the small reed dimensions compared to bamboo, variations concerning the bamboo standards were carried out. Therefore, caution is needed when comparing these results with the results of other research.

Furthermore, the water content was not considered in the discussion of the results. Conte et al. [27] studied the effect of water content on the structural and mechanical properties of reed (AD). The researchers used a combination of different analytical techniques (such as calorimetry and fast field cycling NMR relaxometry). They concluded that reed bending properties are strongly affected by the presence of bound water. Thus, it is important to consider the physical properties of the reed when studying its mechanical properties.

There is an important gap in the knowledge of the physical properties of reed. In recent literature, there has been no research focused on these properties. Some research with mainly thermo-mechanical objectives included the determination of some physical characteristics of the reed. Soliman [28] studied reed (AD) use in thermal insulation and, in parallel, also determined its water absorption and moisture content. After three months of drying the reed, they found $12.11 \%$ of moisture and $52.60 \%$ of water absorption (after immersion in water for $24 \mathrm{~h}$ at a room temperature of $23^{\circ} \mathrm{C}$ ). The moisture content was higher than values achieved in other research [26,29]. This difference could have been related to the test methodology.

In their study focused on mechanical characterisation, Molari et al. [26] determined the moisture content of reed, reaching values between $7.09 \%$ and $8.96 \%$. Ortunõ [29] carried out a reed $(\mathrm{AD})$ characterisation for use as a construction material and determined its moisture content and density. After one year of drying, they determined the reed density as received $\left(583 \mathrm{~kg} / \mathrm{m}^{3}\right)$, the density of anhydrous reed $\left(537 \mathrm{~kg} / \mathrm{m}^{3}\right)$, and the density of saturated reed $\left(1040 \mathrm{~kg} / \mathrm{m}^{3}\right)$. Since the reed used as a construction material does not receive any treatment, they considered the density equal to $583 \mathrm{~kg} / \mathrm{m}^{3}$ and determined its moisture content to be $8.63 \%$. This value was similar to moisture content value found by Molari et al. [26].

Since the properties of natural materials can be site-dependent $[29,30]$ and no characterisation of reed from Portugal was found in previous studies, this research fills a gap in this area of knowledge, thus assuming an innovative position. In the present paper, the characterisation results of Portuguese reed are presented and discussed. This experimental investigation assessed the physical and thermal behaviour of reed and its durability, aiming to produce knowledge that can be used to design new solutions for more sustainable construction and the conservation of vernacular buildings.

\section{Materials and Methods}

\subsection{Specimens}

The giant reed (Arundo donax) used in this research was harvested in Serpa, inland Southern Portugal. The location was chosen due to the abundance of the reed [7] and proximity to areas where the reed has an important presence in vernacular architecture, as mentioned in the previous section.

The harvest took place in winter. In winter, the plant has less sap (it is drier), and, therefore, it can regenerate quickly. The cut stems have less moisture, dry faster, and are less susceptible to biological agents. According to Alentejo's locals, "reed harvested in January lasts all year" [18]. 
The harvested reeds were stored in a laboratory environment $\left(20 \pm 2{ }^{\circ} \mathrm{C}\right.$ and $50 \pm 2 \%$ $\mathrm{RH}$ ) in a vertical position, and they remained there for six months in the drying process. After the dying process, the reeds with cracks or other anomalies were discarded, and the others were identified and classified according to their external diameter. To characterise the reeds, they were divided into three groups: G0_-diameter less than $11 \mathrm{~mm}$; G1-diameter between 11 and $15 \mathrm{~mm}$ (average thickness of $1.6 \mathrm{~mm}$ ); and G2-diameter between 15 and $22 \mathrm{~mm}$ (average thickness of $2.5 \mathrm{~mm}$ ). G0 was discarded because it showed insufficient mechanical resistance, often breaking during the works. G1 and G2 were characterised in three ways: physical properties, thermal properties, and durability.

\subsection{Physical Properties}

Since there are no normative procedures for the characterisation of reeds, the methods used were adapted from other materials. Due to the differences between the complex reed node structure and the reed stem, it was decided to assess the node influence on the results. Thus, in the physical tests, reed samples with and without nodes were studied. For each test, five samples were used (5-cm-length stems).

\subsubsection{Moisture Content}

The moisture content (MC) test was carried out based on the Portuguese Standard $\mathrm{NP}-614$ [31] for wood. The test consisted of drying the sample in an oven $\left(103 \pm 2{ }^{\circ} \mathrm{C}\right)$ until it reached a constant mass. The moisture content was the difference between the wet mass $\left(\mathrm{m}_{0}(\mathrm{~g})\right)$ and the dry mass $\left(\mathrm{m}_{1}(\mathrm{~g})\right)$ divided by the dry mass, according to Equation $(1)$.

$$
\mathrm{MC}=\frac{\left(\mathrm{m}_{0}-\mathrm{m}_{1}\right)}{\mathrm{m}_{1}} \times 100,
$$

\subsubsection{Apparent Density}

The apparent density $(\rho)$ test was carried out based on the Portuguese Standard NP616 [32] for wood. The test consisted of determining the specimen mass and volume at a specific moisture content. The graphic program AutoCAD was used to determine the specimen's volume. The apparent density was the mass $(\mathrm{m}(\mathrm{g}))$ divided by the volume $(v$ $\left.\left(\mathrm{m}^{3}\right)\right)$, according to Equation (2).

$$
\rho=\frac{\mathrm{m}}{\mathrm{v}}
$$

\subsubsection{Dimensional Stability-Retraction}

The linear retraction $(\varepsilon)$ test was carried out based on NP-615 [33] for wood. The test consisted of determining the variation in studied dimensions after saturation and drying. The linear retraction was the difference between the saturated specimen dimensions $\left(l_{1}(\mathrm{~mm})\right)$ and the air-dried specimen dimensions $\left(l_{2}(\mathrm{~mm})\right)$ divided by the oven-dried specimen dimensions $\left(l_{3}(\mathrm{~mm})\right)$, according to Equation (3).

$$
\varepsilon=\frac{\left(l_{1}-l_{2}\right)}{l_{3}} \times 100,
$$

Reed walls' dimensional variations in length, diameter, and thickness were monitored during the test. Concerning diameter, two directions were monitored: 1-3, 2-4 (Figure 3a). Concerning thickness, four points were monitored: 1, 2, 3, and 4 (Figure 3a). Concerning the length, four directions were monitored: 1-1, 2-2, 3-3, and 4-4 (Figure 3b). 


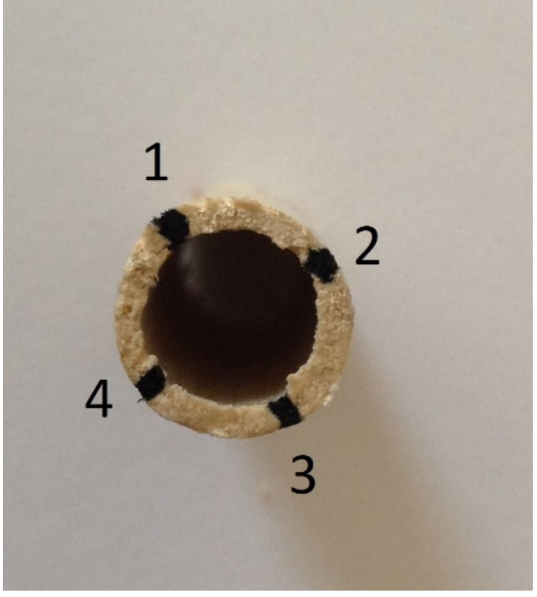

(a)

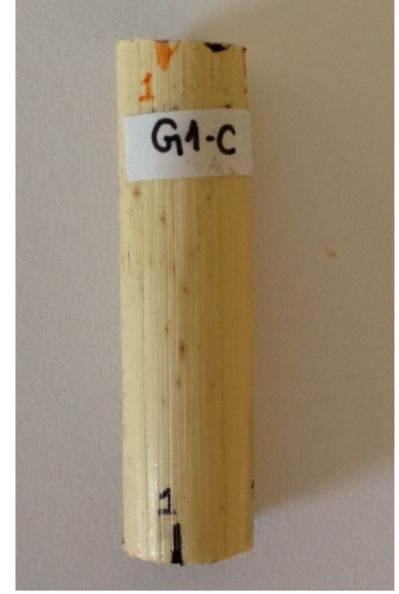

(b)

Figure 3. Markings used in the reeds to carry out the retraction test: (a) diameter and (b) length.

\subsubsection{Capillary Water Absorption}

The principle of the capillary water absorption (A) test consisted of determining the amount of water absorbed by porous materials over a certain time. A dry specimen was placed in an oven at a controlled temperature, and the amount of water absorbed through only one surface of a non-saturated specimen immersed in a water film of $5 \pm 1 \mathrm{~mm}$ was measured. The absorption of water through capillarity was the difference between wet mass $\left(\mathrm{m}_{\mathrm{i}}(\mathrm{g})\right)$ that had one surface in contact with water during a time $\left(\mathrm{t}_{\mathrm{i}}\right)$ and the dry mass $(\mathrm{m}(\mathrm{g}))$ divided by the superficial area that was in contact with water $\left(\mathrm{a}\left(\mathrm{mm}^{2}\right)\right)$, according to Equation (4).

$$
\mathrm{A}_{\mathrm{i}}=\frac{\mathrm{m}_{\mathrm{i}}-\mathrm{m}}{\mathrm{a}},
$$

The samples were dried over $24 \mathrm{~h}$ in an oven at $100 \pm 5{ }^{\circ} \mathrm{C}$. Afterwards, the reed base (external and internal wall) was isolated with silicone to ensure a unidimensional penetration of the water (Figure 4a). A steel wire support was built to prevent the reeds from floating during the test (Figure $4 \mathrm{~b}$ ). The samples were immersed in a water film of $5 \pm 1 \mathrm{~mm}$, and the water level was monitored (Figure 4c). The amount of absorbed water was measured after 15, 30, 60, 90, 120, 150, 180, 210, 240, 300, 360, 1440, and $2880 \mathrm{~min}$ (Figure $4 d$ ).

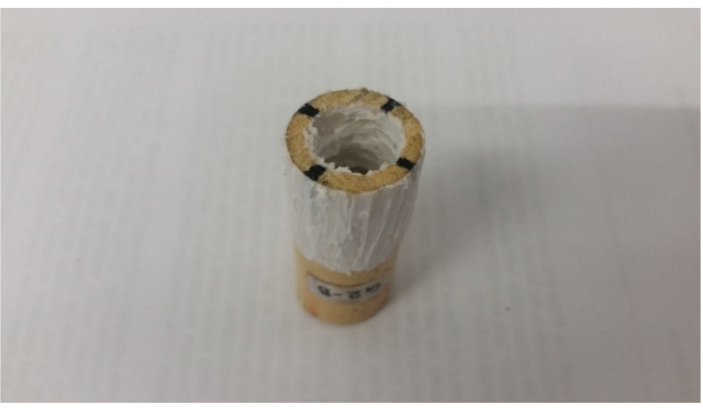

(a)

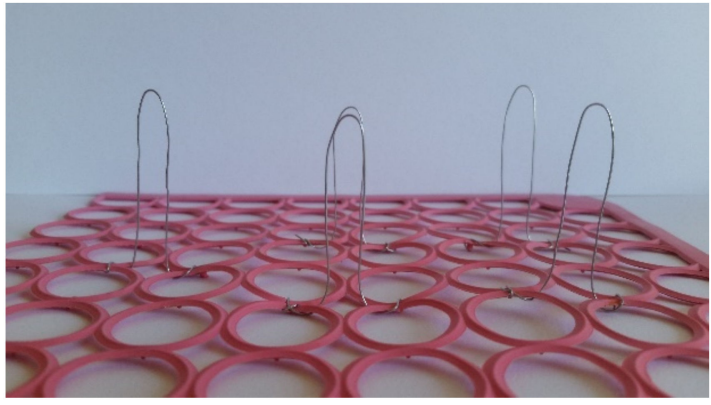

(b)

Figure 4. Cont. 


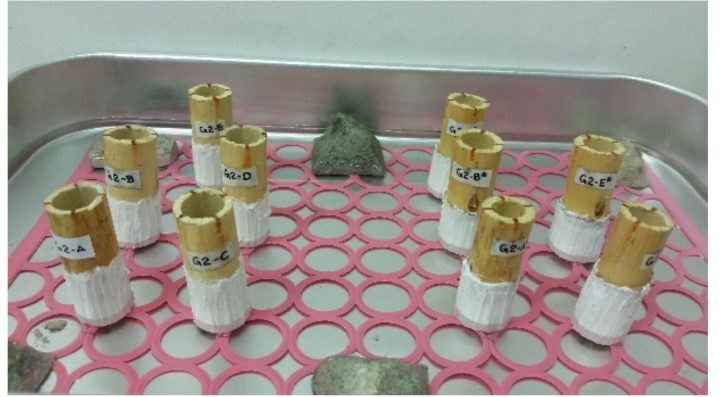

(c)

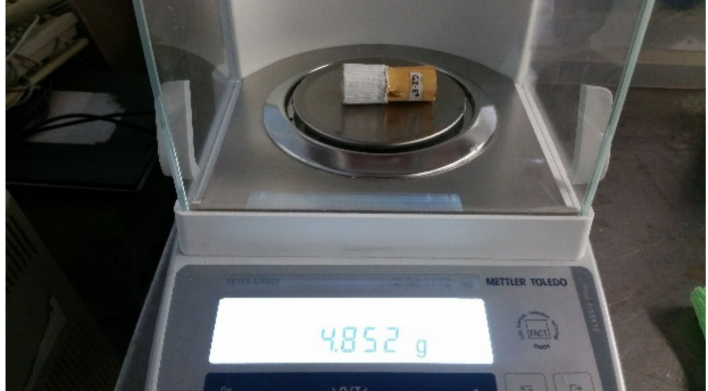

(d)

Figure 4. Capillary water absorption test steps: (a) sample preparation, (b) steel wire support, (c) samples immersed in water, and (d) weighing the sample on a precision balance.

\subsection{Thermal Properties}

The characterisation of the thermal properties of the reed was based on the analysis of its thermal transmittance, thermal resistance, and thermal conductivity. Reed panels were built to analyse these properties using the hotbox test.

\subsubsection{Reed Panels}

Reed panels of $15 \mathrm{~cm} \times 15 \mathrm{~cm}$ (Figure 5a) were built to carry out the calibrated hotbox tests. The reed stems were overlapped to create a $10-\mathrm{cm}$-thick panel (Figure $5 \mathrm{~b}$ ). In order to contain the reed stems, the panels were tied with steel wire. A steel wire was applied in the borders of the panel to decrease the influence on the heat flux during the hotbox test. Two types of panels were built: type 1 (only G1 reeds stalks) and type 2 (only G2 reeds stem). Their main characteristics are presented in Table 1.

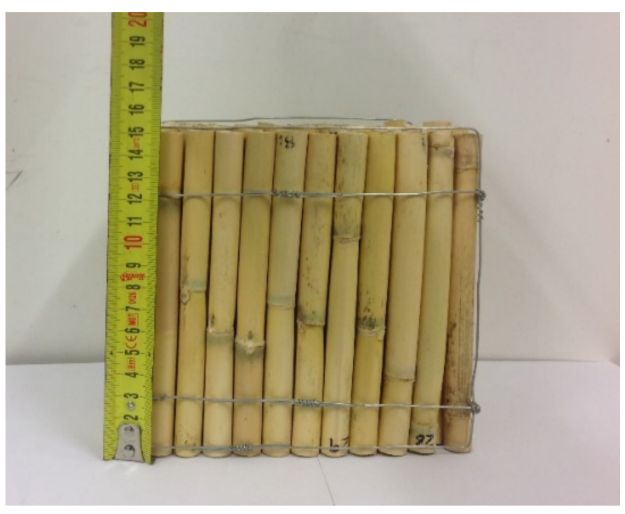

(a)

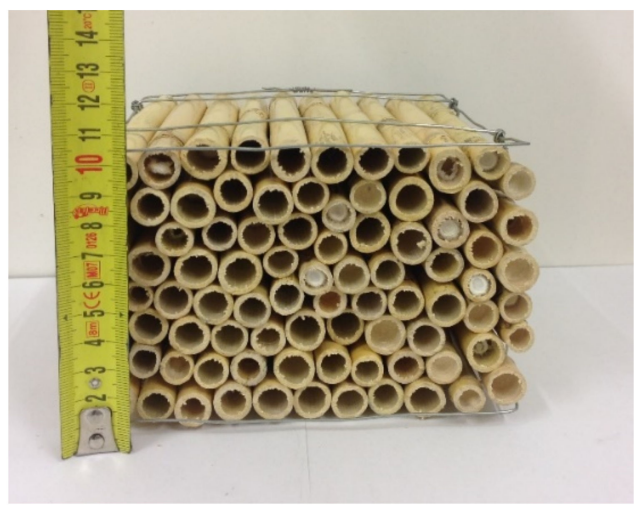

(b)

Figure 5. Reed panels used in hotbox test: (a) horizontal dimensions and (b) thickness.

Table 1. Characteristics of the panels used in the hotbox test.

\begin{tabular}{|c|c|c|c|c|c|c|c|c|c|c|}
\hline ID & $\begin{array}{l}\text { Quantity } \\
\text { of Reed } \\
\text { Stems }\end{array}$ & $\begin{array}{l}\text { Reed Stems } \\
\text { with Nodes } \\
\quad(\%)\end{array}$ & $\begin{array}{l}\text { Quantity } \\
\text { of Nodes }\end{array}$ & $\begin{array}{l}\text { Average } \\
\text { Diameter } \\
(\mathrm{mm})\end{array}$ & $\mathrm{SD}^{1}$ & $\begin{array}{l}\text { Average } \\
\text { Thickness } \\
\text { (mm) }\end{array}$ & SD & $\begin{array}{c}\text { Steel } \\
\text { Wire } \\
\text { Mass (g) }\end{array}$ & $\begin{array}{l}\text { Panel Mass: } \\
\text { Reed and } \\
\text { Wire (g) }\end{array}$ & $\begin{array}{l}\text { Density } \\
\left(\mathrm{kg} / \mathrm{m}^{3}\right)\end{array}$ \\
\hline Type 1 & 84 & $92.31 \%$ & 103 & 13.25 & 0.93 & 1.70 & 0.29 & 19.50 & 489.70 & 208.98 \\
\hline Type 2 & 56 & $100 \%$ & 65 & 16.83 & 1.57 & 2.29 & 0.52 & 19.50 & 479.34 & 204.37 \\
\hline
\end{tabular}

${ }^{1}$ Standard deviation (SD). 


\subsubsection{Hotbox Test}

The thermal properties of the reed were evaluated in a calibrated hotbox [34] designed and built at the Department of Civil Engineering of the University of Minho, following the recommendations of ASTM C1363-11:2014 [35]. The hotbox comprised two five-sided chambers (external dimensions: $2.0 \mathrm{~m} \times 1.4 \mathrm{~m} \times 1.6 \mathrm{~m}$ ) - a cold one and a hot one-and one mounting ring placed between the two chambers. The envelope was well insulated and made of extruded polystyrene (thickness: $0.20 \mathrm{~m} ; \mathrm{U}=0.21 \mathrm{~W} /\left(\mathrm{m}^{2} \cdot{ }^{\circ} \mathrm{C}\right)$ ).

The reed panel was placed in the mounting ring set between the two chambers. It was enclosed between two medium density fibreboards (MDFs) in order to provide a flat surface for installing the flux meter and thermocouples (Figure 6). The reed panels were tested in a horizontal position because the reed accommodation in this position achieved a lower thermal transmittance than the vertical position [21].

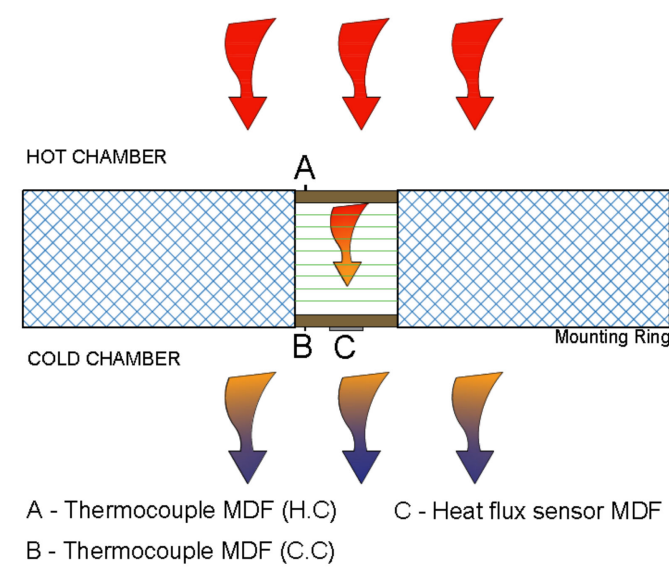

(a)

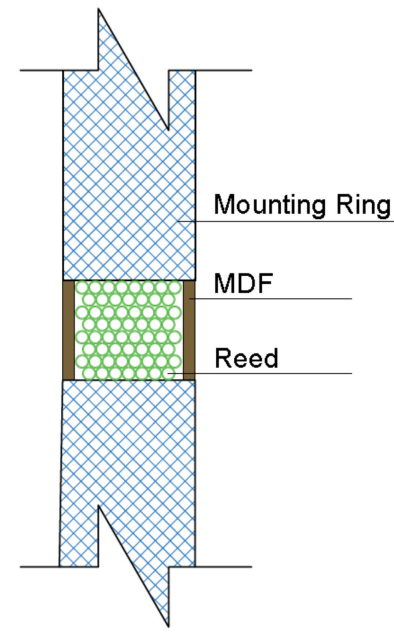

(b)

Figure 6. Set up of reed panel in hotbox test: (a) horizontal view and (b) vertical view.

The temperature difference between the hot and cold chambers was maintained at around $10^{\circ} \mathrm{C}$. The tests were carried out by the thermal flux meter methodology, according to ISO 9869-1:2014 [36], where the heat flux was measured through a heat flux sensor installed in the central part of the reed panel and the temperature was measured by four thermocouples (two in each chamber: one in the middle of the chamber and the other on the surface of the reed panel). With the values of the heat flux (q) and the surface temperatures ( $\mathrm{T})$ while using Equation (5), it was possible to determine the thermal resistance $\left(\operatorname{Re}_{\text {set }}\right)$ of the set (reed panel and MDF), where $\Delta \mathrm{T}$ is the difference between the surface MDF temperature in the hot and cold chambers.

$$
\operatorname{Re}_{\text {set }}\left[\mathrm{m}^{2 \circ} \mathrm{C} / \mathrm{W}\right]=\frac{\Delta \mathrm{T}}{\mathrm{q}},
$$

The thermal resistance of the reed panel ( $\left.\mathrm{Re}_{\text {reed }}\right)$ was determined using Equation (6), where $\operatorname{Re}_{\mathrm{MDF}}$ is the thermal resistance of the MDF used.

$$
\operatorname{Re}_{\text {reed }}\left[\mathrm{m}^{2 \circ} \mathrm{C} / \mathrm{W}\right]=\operatorname{Re}_{\text {set }}-\left(2 * \operatorname{Re}_{\mathrm{MDF}}\right),
$$

The thermal transmittance $\left(\mathrm{U}_{\text {reed }}\right)$ and thermal conductivity $\left(\lambda_{\text {reed }}\right)$ of the reed panel were determined using Equations (7) and (8), where e is the thickness of the panel.

$$
\mathrm{U}_{\text {reed }}\left[\mathrm{W} / \mathrm{m}^{2 \circ} \mathrm{C}\right]=\frac{1}{\operatorname{Re}_{\text {reed }}},
$$




$$
\lambda_{\text {reed }}\left[\mathrm{W} / \mathrm{m}^{\circ} \mathrm{C}\right]=\frac{\mathrm{e}}{\operatorname{Re}_{\text {reed }}}
$$

\subsection{Durability - The Mould Development Test}

Reed is an organic material. As a natural building material, reed becomes mouldy like wood or wood-based products in favourable conditions [37]. Mould is often an early indication of increased moisture levels in buildings. Problems caused by mould are mainly discolouration, odours, and health problems.

In order to evaluate the resistance of the reed for mould growth, an exploratory overstress test was carried out for the samples. The assessment of the emergence and development of mould in the reed samples was made visually with images collected using binocular materials microscope LEICA DM 750 M from Leica Microsystems, a 5 MP HD Microscope Camera Leica MC170 HD (sourced by Leica Microsistemas Lda., Microscopia e Histologia, Carnaxide Portugal) and Leica Application Suite (version 4.12.0).

Four samples in each reed group (G1 and G2) were placed in a Petri dish, visually evaluated, and laid in ARALAB FitoClima 1000EC45 climatic chamber $\left(22 \pm 2{ }^{\circ} \mathrm{C}\right.$ and $90 \pm 5 \%$ HR) for 42 days. The chamber conditions were appropriate for mould development in reed [38]. One reed dried in an oven $\left(103 \pm 2{ }^{\circ} \mathrm{C}\right)$ until reaching a constant weight (G1Dry and G2-Dry), was studied too. The samples were evaluated weekly. To reduce the time the samples were outside the chamber and to avoid changes in the final results, the visual analysis was performed in the shortest possible time of less than $20 \mathrm{~min}$.

During the visual analysis, the quantification of mould growth was based on the mould index used in the experiments for visual inspection (Table 2). To minimise the margin of error, the visual inspection was made independently by two persons.

Table 2. Mould indexing classifications (adapted from [39]).

\begin{tabular}{ccc}
\hline Mould Index & Coverage & Description of Classification \\
\hline 0 & 0 & No growth \\
\hline 1 & 0 & Some growth detected only with microscopy \\
\hline 2 & $>10 \%$ & Moderated growth detected with microscopy \\
\hline 3 & $0-10 \%$ & Some growth detected visually \\
\hline 4 & $10-50 \%$ & Visually detected \\
\hline 5 & $50-80 \%$ & Visually detected \\
\hline 6 & $80-100 \%$ & Visually detected \\
\hline
\end{tabular}

\section{Results and Discussion}

\subsection{Physical Properties}

\subsubsection{Moisture Content}

Figure 7 shows the mass loss as a time function. Similar behaviour was observed in all studied samples, regardless of node presence and group. The samples reached a constant mass after around $240 \mathrm{~min}$. There was a marked mass loss during the first $30 \mathrm{~min}$ of the test, followed by a residual loss up to $24 \mathrm{~h}$. The verified mass loss was related to the water evaporating during the drying process. 


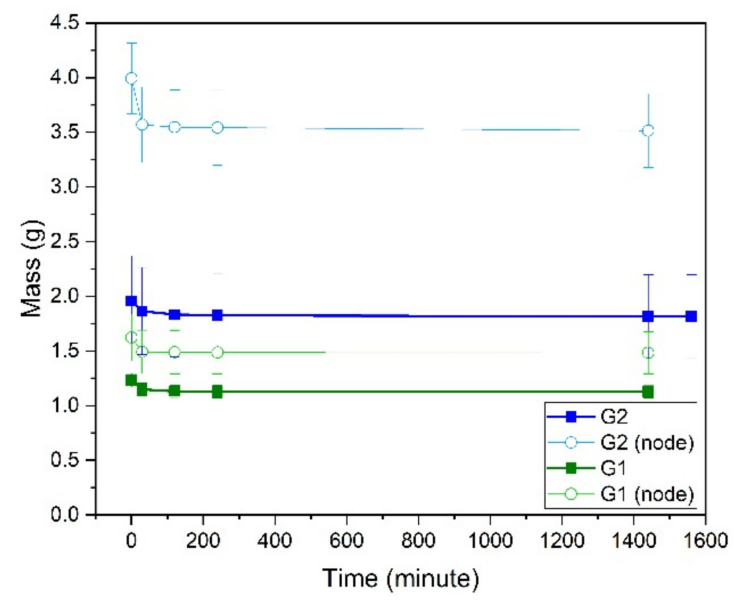

Figure 7. Mass loss of reed as a function of test time.

The results of the moisture content test are presented in Table 3. After six months in the natural drying process (Section 2.1), the reeds showed similar moisture content, regardless of group (G1 or G2). According to the results, the reed diameter (and thickness) had no significant influence on the moisture content. Despite the difference between used methodologies, Molari et al. [26] and Ortunõ [29] studied reed (AD) and found similar moisture content values of $8.96 \%$ and $8.63 \%$, respectively. Nevertheless, they did not evaluate the differences between regions with and without nodes. Concerning node presence, G2 with node showed a higher moisture content than G2 without node. That was not the case with the G1 reed. The presence of the node likely only had an influence on the moisture content for larger diameters. Conte et al. [27] studied node influence on the moisture content of reed (AD), and they also found a higher moisture content in reeds with nodes. The research did not show the diameter of the studied reed. According to the authors, the largest moisture content of the reed with a node could be explained by the presence of a larger amorphous cellulose fraction inside the node compared with the reed without the node.

Table 3. Moisture content of reeds.

\begin{tabular}{ccc}
\hline Identification & Moisture Content (\%) & SD $^{\mathbf{1}}$ \\
\hline G1 & 9.463 & 0.195 \\
G1-node & 9.432 & 0.056 \\
G2 & 9.495 & 0.242 \\
G2-node & 10.28 & 0.150 \\
\hline
\end{tabular}

${ }^{1}$ Standard deviation.

The values present in Table 3 are close to the moisture values for wood showed in Portuguese standard (12\% [31]) and those expected for bamboo after the natural drying process, i.e., between $10 \%$ and $15 \%$ [40]. In this sense, it is possible to say that, after six months of natural drying, regardless of the diameter and node presence, the reed could reach moisture levels close to the reference values for wood and bamboo.

\subsubsection{Apparent Density}

Density is related to most physical properties of materials. Therefore, it becomes an indicator of the quality of natural materials and their possible applications. The higher the density, the higher the resistance and the better the quality [29]. Reed density can vary between its base and its tip, and it depends on its age: the more mature the reed, the denser it is [41]. The studied stems were from the middle part of the reed and were between one and two years of age. The graph presented in Figure 8 shows the density values found in this study and their comparison with bamboo and other wood materials used in construction. 


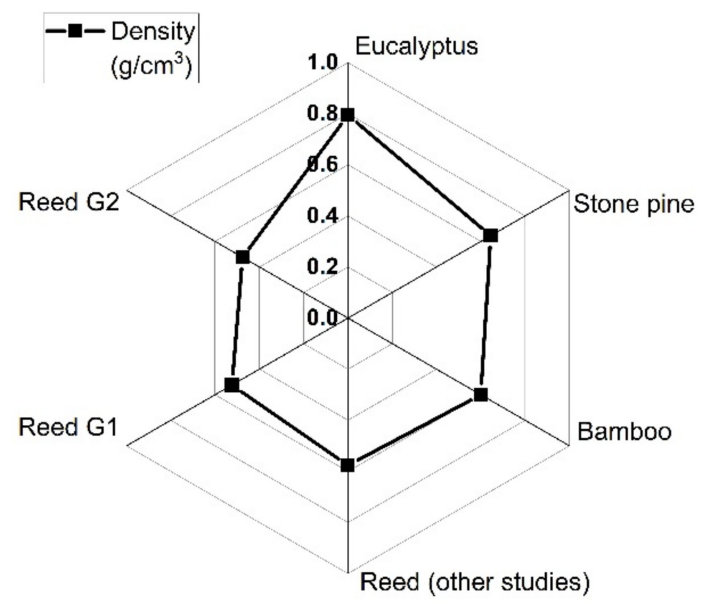

Figure 8. Density of the studied reed (G1 and G2), bamboo, and other wood materials used in the construction.

From the comparison of the different groups, it is possible to observe a slight difference between the density values. G1 at $0.524 \mathrm{~g} / \mathrm{cm}^{3}$ (SD 0.063 ) showed a greater density than G2 at $0.476 \mathrm{~g} / \mathrm{cm}^{3}$ (SD 0.011). These values were in accordance with other studies, namely that of Molari et al. [26], $0.577 \mathrm{~g} / \mathrm{cm}^{3}$, and Ortunõ [29], $0.583 \mathrm{~g} / \mathrm{cm}^{3}$. Regarding bamboo, for example, the density varies according to the species $\left(0.6\right.$ and $1.0 \mathrm{~g} / \mathrm{cm}^{3}$ [40]). No studies were found on the relationship between reed' physical properties and its different species. Regarding the wood used in construction, reed density (G1 and G2) is close to the density of stone pine: $0.645 \mathrm{~g} / \mathrm{cm}^{3}$ [42].

\subsubsection{Dimensional Stability-Retraction}

Because it is a hygroscopic material, reed changes its moisture content according to the relative air humidity, expanding with increasing humidity levels and retracting with decreasing levels. Thus, the dimensional stability of reed plays an important role in its use in construction, whether in the renovation interventions of heritage or new applications.

The results of the linear retraction in length, diameter, and thickness of the reed are shown in Figure 9. The observed retraction values revealed a specific behaviour for each studied part from the reed stem. For example, regardless of the group and node presence, the thickness of the reed had the highest retraction percentage and the length had the lowest, always less than $1 \%$. Concerning length, the found values were similar to those of bamboo from Portugal retraction $(0.23 \%)$ obtained in [43].

Figure 9 shows that the presence of the node had a more significant influence on G2 than G1, particularly in the reed thickness retraction. The node's influence was more significant in point " 1 " (G2), where the reed with node showed a retraction in thickness that was 1.80 times greater than the reed without node. Regarding the retraction in diameter, the node presence had no influence in G1 but had a slight influence in G2. Regarding the retraction in length, the values were negligible regardless of the group.

In general, the results showed that the reeds with larger diameters tended to present greater retraction, despite their nodes being less vulnerable to this phenomenon. The thickness retraction reached significant values for G1 and G2. Nevertheless, this behaviour must be considered when reeds are used in situations that require greater geometric stability. This high retraction can also influence cases where reeds are used with joints and accessories. 


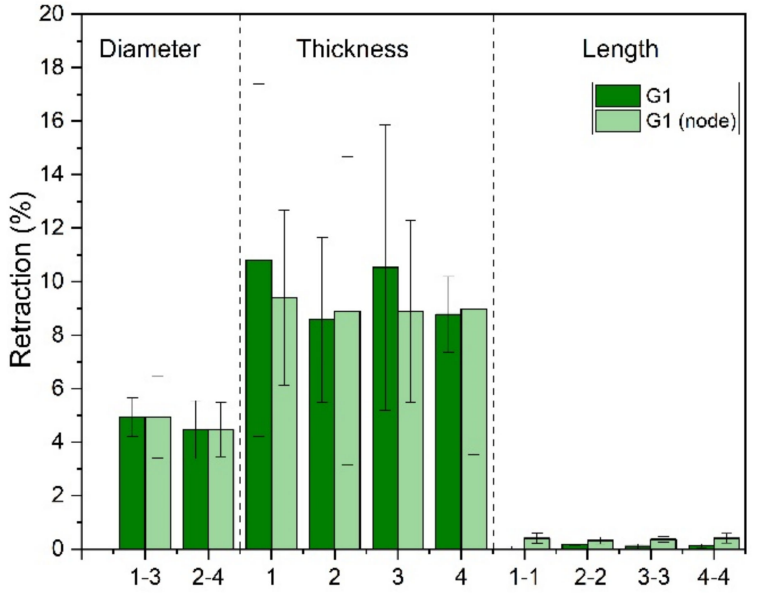

(a)

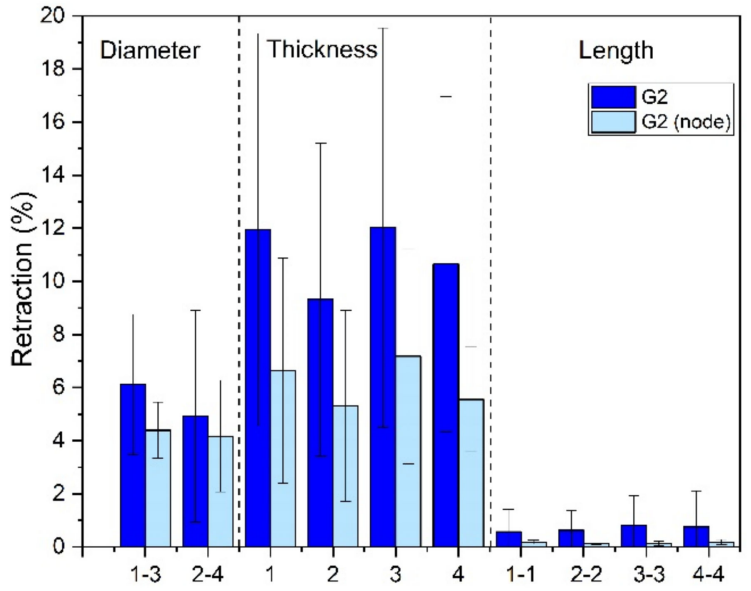

(b)

Figure 9. Linear retraction percentage: (a) G1 and (b) G2.

\subsubsection{Capillary Water Absorption}

The curves shown in Figure 10a illustrate the variation of capillary water absorption as a function of the square root of test time. Figure 10b shows the first stage of the test (first $360 \mathrm{~min}$ ) in detail.

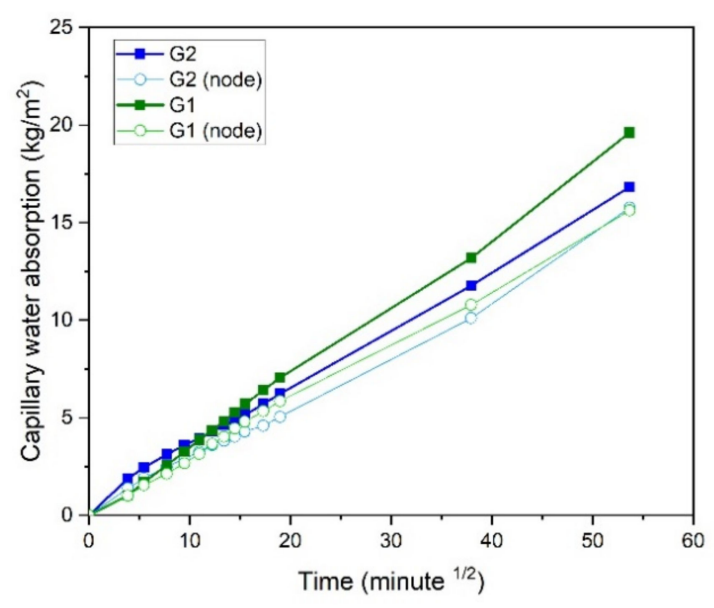

(a)

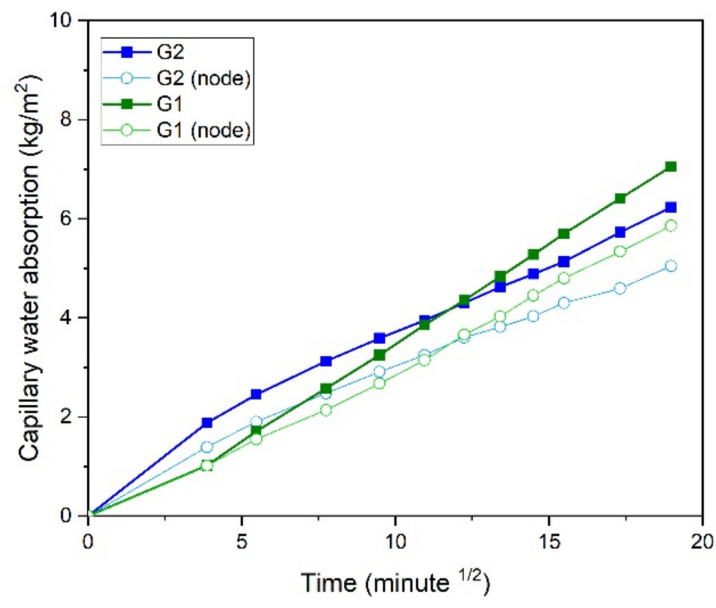

(b)

Figure 10. Capillary water absorption as a function of the square root of test time: (a) complete curves and (b) detail.

According to Figure 10a, until $48 \mathrm{~h}$, none of the samples reached a saturation stage. This behaviour may have been related to the hygroscopic nature of the material and showed that the reed could absorb a high amount of water. This high water absorption was in accordance with the results of a study by Soliman [28]. Though they used another method to assess water absorption (total immersion of reed in water during $24 \mathrm{~h}$ ), they also found a high water absorption value of $52.60 \%$.

Concerning the node presence, it was observed that the samples with nodes absorbed less water than samples without nodes. This "difficulty" in water transport may be related to the dense and complex structure of the node. Reed nodes are likely to be similar to bamboo nodes. In bamboo, the fibrovascular bundles (which transport water and nutrients) are parallel in the stem region, but have a random distribution in the node region [44]. This complex arrangement can make the transportation of water difficult. The retraction test also presented results that corroborated this difference in behaviour between regions without and with nodes. 
Concerning groups, G2 absorbed less water than G1. In addition, the lower slope of the curves (Figure 10b) shows that the capillary absorption of G2 was also the slowest. As such, it is likely that the fibrovascular bundles of G2 were smaller than those of G1. Though the capillary water transport in G1 was faster than G2, the transport occurred throughout the reed stem regardless of diameter and resulted in a very similar moisture content for both groups of around 9\% (Table 3).

\subsection{Thermal Properties}

An infrared camera (ThermaCAMTM T400, FLIR Systems AB, Danderyd, Sweden) was used to evaluate the distribution and homogeneity of the temperatures in the hotbox during the test, as well as to detect the presence of thermal bridges or discontinuities. Figure 11 shows the uniformity of temperatures in the cold chamber and no thermal bridges. It is also possible to observe the hot air outlet in the upper ventilation grid.

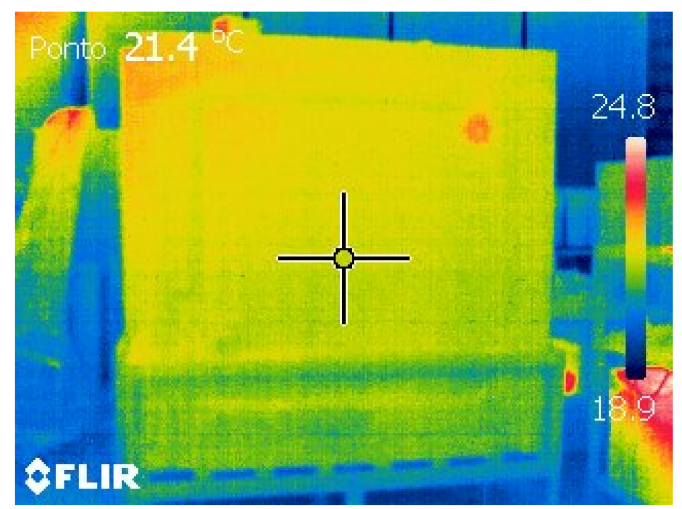

Figure 11. Infrared image from the cold side of hotbox during the test with the reed panel.

The parameters monitored during the hotbox test are shown in Figure 12. Figure 12a refers to the results of panel type 1 (G1), and Figure $12 \mathrm{~b}$ refers to the results of panel type 2 (G2).

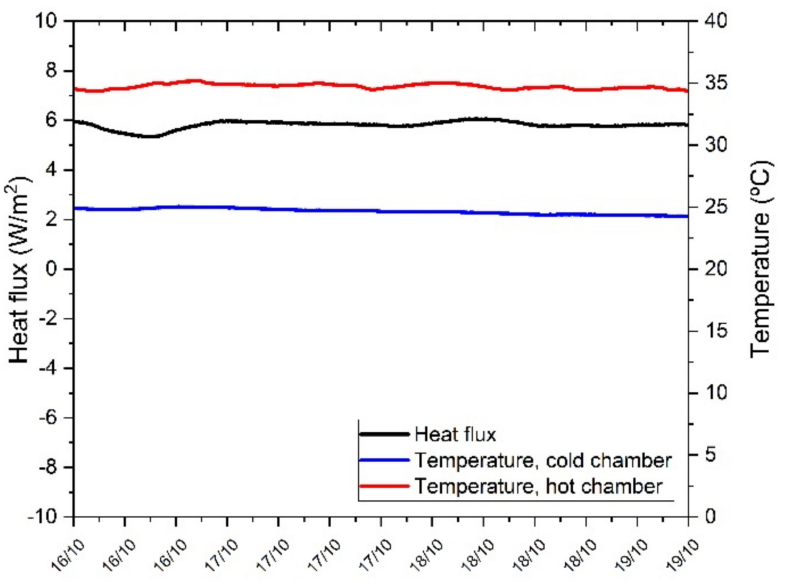

(a)

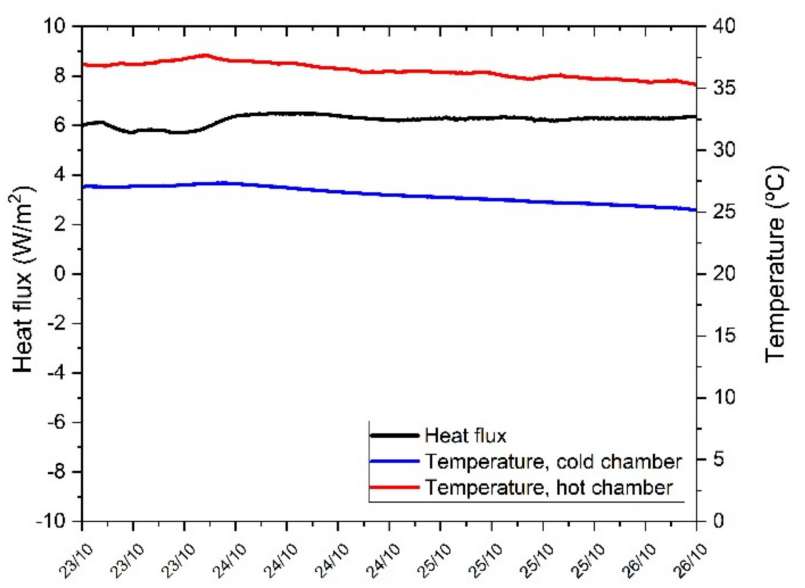

(b)

Figure 12. Measurements of the heat flux and hot and cold superficial temperatures in the set: (a) panel reed G1 and MDF; (b) panel reed G2 and MDF.

From Figure 12, it can be seen that despite the heterogeneity of this natural material, the temperature and the heat flux remained stable during the test period $(72 \mathrm{~h})$. In the type 1 (G1) test, the cold chamber remained very stable, maintaining a temperature of $24^{\circ} \mathrm{C}$ and the hot chamber temperature remained near $34^{\circ} \mathrm{C}$. In the type $2(\mathrm{G} 2)$ test, the 
cold chamber showed an average temperature near $26{ }^{\circ} \mathrm{C}$ and the hot chamber showed an average temperature near $36^{\circ} \mathrm{C}$.

Based on the results from Figure 12 and the application of the equations presented in Section 2.3.2, Table 4 summarises the average values obtained for the thermal properties of the studied reed panels.

Table 4. Parameters monitored during the hotbox and the thermal properties of the studied reed panels.

\begin{tabular}{|c|c|c|c|c|c|c|c|}
\hline \multirow{2}{*}{ Panel } & \multicolumn{2}{|c|}{ Superficial Temperature $\left({ }^{\circ} \mathrm{C}\right)$} & \multirow{2}{*}{$\begin{array}{l}\text { Heat Flux } \\
\left(\mathrm{W} / \mathrm{m}^{2}\right)\end{array}$} & \multirow{2}{*}{$\begin{array}{c}\operatorname{Re}_{\text {set }} \\
\left(\mathrm{m}^{2} \cdot{ }^{\circ} \mathrm{C} / \mathrm{W}\right)\end{array}$} & \multirow{2}{*}{$\begin{array}{c}\operatorname{Re}_{\mathrm{MDF}} \\
\left(\mathrm{m}^{2} \cdot{ }^{\circ} \mathrm{C} / \mathrm{W}\right)\end{array}$} & \multirow{2}{*}{$\begin{array}{c}\mathrm{Re}_{\text {reed }} \\
\left(\mathrm{m}^{2} \cdot{ }^{\circ} \mathrm{C} / \mathrm{W}\right)\end{array}$} & \multirow{2}{*}{$\begin{array}{c}\lambda_{\text {reed }} \\
\left(\mathrm{W} / \mathrm{m} \cdot{ }^{\circ} \mathrm{C}\right)\end{array}$} \\
\hline & Hot Chamber & Cold Chamber & & & & & \\
\hline Type 1 & 34.66 & 24.66 & 5.61 & 1.834 & 0.147 & 1.540 & 0.064 \\
\hline Type 2 & 36.37 & 26.37 & 5.88 & 1.886 & 0.147 & 1.592 & 0.063 \\
\hline
\end{tabular}

According to Table 4, type 1 (G1) and 2 (G2) panels showed similar thermal behaviour. From the results of the performed measurements, two main aspects can be discussed. First, the type 1 (G1) panel had almost twice as many nodes as the type 2 (G2) panel (Table 1). Thus, the number of nodes had no significant influence on the thermal behaviour of the reed panels. Second, the panels were built with similar densities to assess the influence of reed diameter (Table 1$)$. For the studied diameter range (11-22 $\mathrm{mm}$ ), the reed diameter had no significant influence on the thermal properties of the reed panels. These results were in accordance with those of Asdruballi et al. [22], a study where reeds (PA) with diameters between 3.6 and $8.8 \mathrm{~mm}$ were analysed using a guarded hot plate and hotbox test, and conclusions showed that the diameter did not influence thermal conductivity [22]. The studied reed panels showed a good thermal behaviour regardless of the studied group.

Considering the thickness of the reed panels $(100 \mathrm{~mm})$, their thermal resistance values represented $60 \%$ of the thermal resistance value of some commercially used insulation materials such as rock wool, XPS, and cork (approximately $2.60 \mathrm{~m}^{2} \cdot{ }^{\circ} \mathrm{C} / \mathrm{W}$ ). The obtained thermal conductivity values were similar to those presented in other studies (using reed from different origins) $[22,44]$ and corroborated this type of reed potential for use as a thermal insulation material.

\subsection{Durability—The Mould Growth Test}

To analyse the moisture content's influence on the durability of the natural materials, reed (without nodes) was subjected to two drying processes: the natural process (G1 and G2) and the oven drying process (G1-Dry and G2-Dry). The quantification of mould growth is shown in Figure 13.

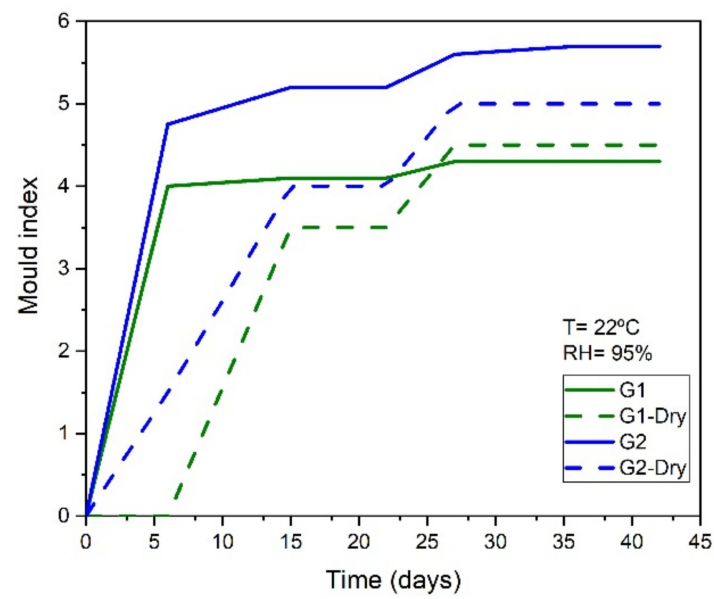

Figure 13. The mould index of the reed as a function of the test time. 
From Figure 13, it can be seen that the growth of mould was detected in all studied situations. The mould growth intensity was different depending on the reed group and drying process. G2 had a more intense mould growth than G1 during the entire test period, regardless of the drying process. This behaviour could have been related to the G2 thickness. Its greater thickness than G1 could provide a larger surface for mould development. Since the moisture content of the two groups was similar (Table 3), it is believed that this variable did not influence this specific behaviour.

Concerning the drying process, it is possible to say that reference samples (G1-Dry and G2-Dry) had a less intense mould growth than those subjected to the natural drying process (G1 and G2). In this specific behaviour, moisture content was found to play an important role since the higher moisture content (G1 and G2) provided a more favourable environment for mould development. Tables 5 and 6 show mould growth observations for the larger (G2) and smaller (G1) mould growth intensities observed in this study. In Tables 5 and 6 , it is possible to compare the mould index and the images of the samples at four different test moments: $0,14,28$, and 42 days.

Table 5. Development of surface moulds in G1 dry reed.

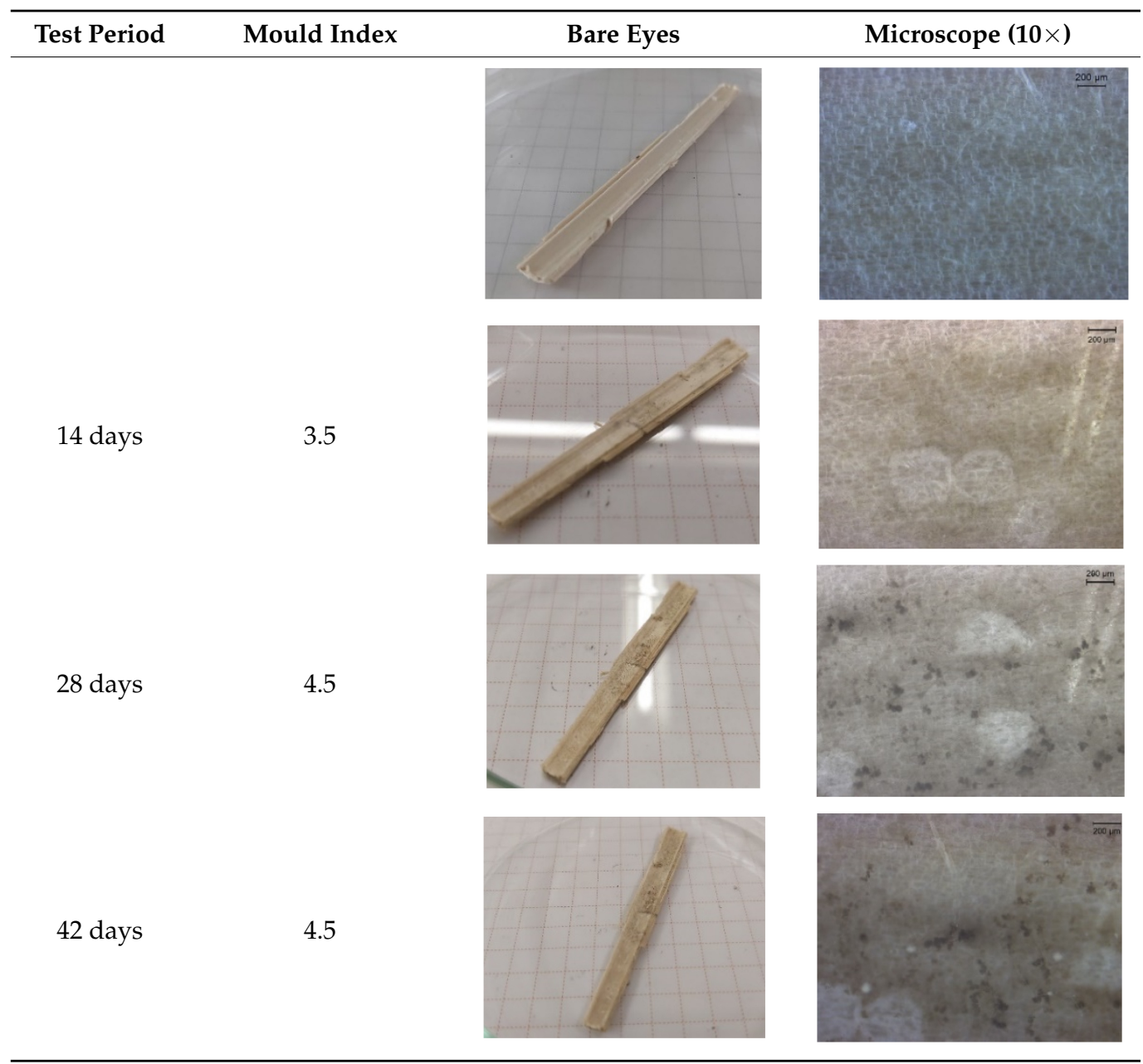


Table 6. Development of surface moulds in G2 reed.

\begin{tabular}{|c|c|c|c|}
\hline Test Period & Mould Index & Bare Eyes & Microscope $(10 \times)$ \\
\hline 0 day & 0 & & \\
\hline 14 days & 5 & & \\
\hline 28 days & 5.5 & & \\
\hline 42 days & 6 & & \\
\hline
\end{tabular}

The general aspects of the samples presented in Tables 5 and 6 are quite different. In the photographs corresponding to the bare-eyes analysis, it is possible to observe intense dark areas in the G2 sample, while in the G1-Dry sample, a generalised brown colour was observed. The microscope images show the evolution of the mould in the sample at the same point of the test.

In the G2 sample, the fifth stage of growth (index 5) was reached after 14 days of testing. The bare-eyes analysis showed that almost $80 \%$ of the sample was covered with grey and black mould. After 14 days, the mould growth was moderate, and the last stage of mould growth (index 6) was reached at the end of the test. In this stage, it was possible to see, in the microscope image, a high density of mould in the sample. In the G1-Dry sample, the third stage of growth (index 3) was reached after 14 days of testing, and the maximum growth stage did not exceed index 4 . Grey and black mould was observed in the microscope image only after 28 days, and the sample showed a low density of mould growth until the end of the test.

These results show the trend in the development of mould in the studied reeds. The interior surfaces of the reeds were studied individually, but the results were in accordance with the study of [37]. In this research, [37] reeds tied with steel wire were subjected to the overstress test $\left(22^{\circ} \mathrm{C}\right.$ and $90 \% \mathrm{HR}$ ), and at the end of 42 days, the external surfaces of the reeds showed a mould development index between 5 and 6 . The results of this study also showed the important role played by moisture content in the durability context. Drier reeds lead to less intense and slower mould growth. 
These results confirmed the trend in the development of mould in the studied reed. However, these results must be carefully analysed. There are two main aspects to consider. First, the chamber conditions were the ones that maximise mould growth in reed [38]. Similar conditions could occur in particular natural environments. In Portugal, for example, only the coastal region reaches temperature and humidity conditions similar to those studied. This situation can happen during the summer for a short time, usually at night [10]. Second, the reed was studied while considering the resistance to the mould of the inner face, i.e., the most vulnerable one. This area is the less dense side of the reed [41] and is therefore more vulnerable to aggressive agents.

\section{Conclusions}

To reduce the environmental impact of the construction sector, preserve and renovate vernacular buildings, and create commercial value for locally available natural materials such as the giant reed (Arundo donax), it is necessary to know a material's physical and thermal proprieties.

Reed is considered to a carbon-neutral raw material and a carbon dioxide sink, and it has been used for centuries for diverse uses. Its high availability and properties made it a popular building material, including in the construction of Portuguese vernacular buildings.

In the present paper, an experimental study was carried out to characterise the giant reed (Arundo donax) that is most common in Portugal. Considering the uses of reed in Portuguese vernacular architecture (as for thermal insulation) and the absence of data on the physical properties of the reed, its thermal and physical properties were assessed in this study. The durability of natural materials plays an important role in this context, so it was also evaluated in this study. The results were presented and discussed in the previous sections, and the main conclusions are as follows:

(1) Based on the studied thermal parameters (thermal resistance, thermal transmittance, and thermal conductivity), it is possible to conclude that reed from Portugal, under the studied conditions, has an adequate thermal performance. Furthermore, its thermal resistance $\left(1.8 \mathrm{~m}^{2} \cdot{ }^{\circ} \mathrm{C} / \mathrm{W}\right)$ and thermal conductivity $\left(0.06 \mathrm{~W} / \mathrm{m} \cdot{ }^{\circ} \mathrm{C}\right)$ were found to be in accordance with the requirements defined by Portuguese law for thermal insulation materials. The thermal resistance of reed is almost $60 \%$ of the insulation materials used in Portugal (e.g., rock wool, XPS, and cork). The geometric characteristics (diameter) and node presence were found to have no influence on the studied thermal properties.

(2) The physical characteristics of reed from Portugal are compatible with its use as a construction material. The reed's density and water content were found to be similar to the organic materials conventionally used in the construction sector. The reed has satisfactory dimensional stability, making it compatible with rigid connection accessories. However, attention should be paid to aspects such as retraction in its thickness. The hygroscopic nature of reed could be related to the high water absorption reached in the tests.

(3) There is a trend for mould growth under favourable conditions $\left(22 \pm 2{ }^{\circ} \mathrm{C}\right.$ and $90 \pm 5 \%$ HR). Nevertheless, these specific temperature and humidity conditions are uncommon in Portuguese climatic conditions. Therefore, the durability of this material will not hinder its use as a building material.

The presented characterisation provides valuable data to be considered in the renovation of vernacular buildings. In addition, regarding the studied samples, the reed found in Portugal has characteristics suitable for use as a building material, especially as a thermal insulation material. Additionally, considering the abundance of reed throughout the Portuguese territory, this is a sustainable, eco-friendly, and low-cost option. 
Author Contributions: R.M. (Raphaele Malheiro) and A.A. undertook the main part of the research that was the base of this article. They developed the research method and analysed the results with the contribution of C.G. and J.F. R.M. (Raphaele Malheiro) wrote the document with the input of S.M.S. and R.M. (Ricardo Mateus). S.M.S. and R.M. (Ricardo Mateus) helped to develop the discussion sections of the paper and provided critical judgment on the undertaken research. Additionally, they supervised all the works and revised the document. M.T.A. helped in the durability tests (development and data analyse). All authors have read and agreed to the published version of the manuscript.

Funding: The authors would like to acknowledge the support granted by the FEDER funds through the Competitively and Internationalization Operational Programme (POCI) and by national funds through FCT (the Foundation for Science and Technology) within the scope of the project with the reference POCI-01-0145-FEDER-029328, reVer+.

Institutional Review Board Statement: Not applicable.

Informed Consent Statement: Not applicable.

Acknowledgments: The authors would like to acknowledge the support granted by DANOSA "Derivados asfálticos normalizados, S.A." industry for the hotbox construction by providing all the necessary insulation material.

Conflicts of Interest: The authors declare no conflict of interest.

\section{References}

1. Allirand, J.-M.; Gosse, G. An above-ground biomass production model for a common reed (Phragmites communis Trin.) stand. Biomass Bioenergy 1995, 9, 441-448. [CrossRef]

2. Köbbing, J.F.; Thevs, N.; Zerbe, S. The utilisation of reed (Phragmites australis): A review. Int. Mire Conserv. Group Int. Peat Soc. 2013, 13, 1-14.

3. Barreca, F. Use of giant reed Arundo Donax L. in rural constructions. Agric. Eng. Int. CIGR J. 2012, 14, 46-52.

4. Zámolyi, F.; Herbig, U. Reed as building material-renaissance of vernacular techniques. In International Symposium on Advanced Methods of Monitoring Reed Habitats; Csaplovics, E., Schmidt, J., Eds.; Rhombos Verlag Berlin: Berlin, Germany, 2011 ; p. 83.

5. Speck, O.; Spatz, H.-C. Damped oscillations of the giant reed Arundo donax (Poaceae). Am. J. Bot. 2004, 91, 789-796. [CrossRef]

6. Barreca, F.; Martinez, A.; Flores, J.A.; Pastor, J.J. Innovative use of giant reed and cork residues for panels of buildings in Mediterranean area. Resour. Conserv. Recycl. 2019, 140, 259-266. [CrossRef]

7. Arundo donax Flora-On. Available online: https://flora-on.pt/\#/1Arundo+donax (accessed on 11 March 2021).

8. AAVV. Arquitectura Popular em Portugal; Associação dos Arquitetos Portugueses: Lisboa, Portugal, 1988.

9. Mestre, V. Arquitetura Popular da Madeira; Argumentum: Lisboa, Portugal, 2002.

10. Fernandes, J.; Malheiro, R.; Castro, M.D.F.; Gervásio, H.; Silva, S.M.; Mateus, R. Thermal Performance and Comfort Condition Analysis in a Vernacular Building with a Glazed Balcony. Energies 2020, 13, 624. [CrossRef]

11. Fernandes, J. O Contributo da Arquitectura Vernacular Portuguesa para a Sustentabilidade dos Edifícios. Ph.D. Thesis, University of Minho, Guimarães, Portugal, 2012.

12. Cravinho, A. Pedra \& Cal n.24; Rua Pedro Nunes: Lisboa, Portugal, 2004; pp. 12-13.

13. Fernandes, J.; Mateus, R.; Gervásio, H.; Silva, S.; Branco, J.; Almeida, M. Thermal Performance and Comfort Conditions Analysis of a Vernacular Palafitic Timber Building in Portuguese Coastline Context. Sustainability 2020, 12, 10484. [CrossRef]

14. Ferreira, D.M.; Araújo, A.; Fonseca, E.M.; Piloto, P.; Pinto, J. Behaviour of non-loadbearing tabique wall subjected to fireExperimental and numerical analysis. J. Build. Eng. 2017, 9, 164-176. [CrossRef]

15. Sá, A.B.; Pereira, S.; Soares, N.; Pinto, J.; Lanzinha, J.C.; Paiva, A.; Cunha, S.P.D.S. An approach on the thermal behaviour assessment of tabique walls coated with schist tiles: Experimental analysis. Energy Build. 2016, 117, 11-19. [CrossRef]

16. Fonseca, I.F.P. Permanência e Transformação: Contributos para a Utilização de Materiais Modernos na Conservação do Património Arquitetónico. Os Produtos Técnicos de Madeira; University of Évora: Évora, Portugal, 2014.

17. Barroso, C.E.; Oliveira, D.V.; Ramos, L.F. Physical and mechanical characterization of vernacular dry stone heritage materials: Schist and granite from Northwest Portugal. Constr. Build. Mater. 2020, 259, 119705. [CrossRef]

18. Ribeiro, V. (Ed.) Materiais, Sistemas e Técnicas de Construção Tradicional-Contributo para o Estudo d Arquitetura Vernácula da Região Oriental da Serra do Caldeirão; Edições Afrontamento e CCDR Algarve: Faro, Portugal, 2008.

19. Arundo donax vs. Phragmites australis. Available online: http://desertfishes.org/cuatroc/organisms/arundo-vs-phragmites.html (accessed on 24 March 2021).

20. Speck, O.; Spatz, H.-C. Mechanical Properties of the Rhizome of Arundo donax L. Plant Biol. 2003, 5, 661-669. [CrossRef]

21. Miljan, M.; Miljan, M.-J.; Miljan, J.; Akermann, K.; Karja, K. Thermal transmittance of reed-insulated walls in a purpose-built test house. Mires Peat 2014, 13, 1-12. 
22. Asdrubali, F.; Bianchi, F.; Cotana, F.; D’Alessandro, F.; Pertosa, M.; Pisello, A.L.; Schiavoni, S. Experimental thermo-acoustic characterization of innovative common reed bio-based panels for building envelope. Build. Environ. 2016, 102, 217-229. [CrossRef]

23. Barreca, F.; Fichera, C.R. Wall panels of Arundo donax L. for environmentally sustainable agriculture buildings: Thermal performance evaluation. J. Food Agric. Environ. 2013, 11, 1353-1357.

24. Asdrubali, F.; D'Alessandro, F.; Schiavoni, S. A review of unconventional sustainable building insulation materials. Sustain. Mater. Technol. 2015, 4, 1-17. [CrossRef]

25. Carneiro, P.; Jerónimo, A.; Faria, P. Reed-Cob: Tecnologia Inovadora de Baixo Carbono para Construção de Pequeno Porte. In II Encontro Nacional Sobre Reabilitação Urbana e Sustentabilidade; iiSBE Portugal \& Universidade do Minho: Lisboa, Portugal, 2017.

26. Molari, L.; Coppolino, F.S.; García, J.J. Arundo donax: A widespread plant with great potential as sustainable structural material. Constr. Build. Mater. 2021, 268, 121143. [CrossRef]

27. Conte, P.; Fiore, V.; Valenza, A. Structural and Mechanical Modification Induced by Water Content in Giant Wild Reed (A. donax L.). ACS Omega 2018, 3, 18510-18517. [CrossRef]

28. Soliman, M. Arundo donax L. and Its Use in the Thermal Insulation in Architecture to Decrease the Environmntal Pollution; Ain Shams University: Cairo, Egypt, 2009.

29. García-Ortuño, T. Caracterización de la Caña Común (Arundo donax L.) para su Uso Como Material de Construcción; Universidad Miguel Hernández: Alicante, Spain, 2003.

30. Volf, M.; Diviš, J.; Havlík, F. Thermal, Moisture and Biological Behaviour of Natural Insulating Materials. Energy Procedia 2015, 78, 1599-1604. [CrossRef]

31. IPQ NP-614. Wood-Determination of Water Content (in Portuguese); IPQ NP-614: Lisboa, Portugal, 1973; p. 2.

32. IPQ NP-616. Wood-Determination of Density (in Portuguese); IPQ NP-616: Lisboa, Portugal, 1973; p. 2.

33. IPQ NP-615. Wood-Determination of Retraction (in Portuguese); IPQ NP-615: Lissboa, Portugal, 1973.

34. Teixeira, E.R.; Machado, G.; De Adilson, P.; Guarnier, C.; Fernandes, J.; Silva, S.M.; Mateus, R. Mechanical and thermal performance characterisation of compressed earth blocks. Energies 2020, 13, 2978. [CrossRef]

35. ASTM International. ASTM C1363-11 Standard Test Method for Thermal Performance of Building Materials and Envelope Assemblies by Means of a Hot Box Apparatus 1. Am. Soc. Test. Mater. 2014, 90, 1-44.

36. ISO-9869. Thermal Insulation-Building Elements-In-Situ Measurement Thermal Resistance and Thermal Transmittance; International Organization for Standardization: Geneva, Switzerland, 1994; Volume 994, p. 24.

37. Lautkankare, R. The mold test. In Guidebook of Reed Business; Ülo, K., Ed.; Tallinn University of Technology: Tallinn, Estonia, 2013; pp. 42-45. ISBN 978-9949-484-91-1.

38. Bergholm, J. Susceptibility to Microbial Growth of Common Reed and Other Construction Materials; Turku University of Applied Sciences: Turku, Finland, 2012.

39. Hukka, A.; Viitanen, H.A. A mathematical model of mould growth on wooden material. Wood Sci. Technol. 1999, 33, 475-485. [CrossRef]

40. Liese, W. The Anatomy of Bamboo Culms; International Network for Bamboo and Rattan: Beijing, China, 1998 ; ISBN 8186247262.

41. Couvreur, L.; Alejandro Buzo, R. Construir con Caña-Estudio del uso de la Caña en la Arquitectura Tradicional y de su Recuperación para la Construcción Contemporánea; Catálogo de publicaciones del Ministerio: Madrid, Spain, 2019. Available online: www. culturaydeporte.gob.es (accessed on 13 June 2021).

42. Dias, J.R. Caracterization of the Stone Pine Timber (in Portuguese); University of Coimbra: Coimbra, Portugal, 2019.

43. Freitas, M.P. Análise Prática das Propriedades Físicas e Mecânicas do Bambu Phyllostachys edulis, Cultivado em Portugal; University of Minho: Guimarães, Portugal, 2019.

44. Rusch, F.; Éverton, H.; Ceolin, G.B. Anatomia de hastes adultas de bambu: Uma revisão. Pesqui. Florest. Bras. 2018, $38,38$. [CrossRef] 